Primljen / Received: 10.6.2013.

Ispravljen / Corrected: 5.10.2013.

Prihvaćen / Accepted: 15.10.2013.

Dostupno online / Available online: 10.11.2013.

\section{Truss girder joint with a large diameter mechanical fastener}

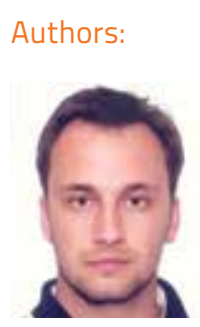

Krunoslav Pavković, PhD. CE

Polytechnic of Zagreb

Building department

krunoslav.pavkovic@tvz.hr

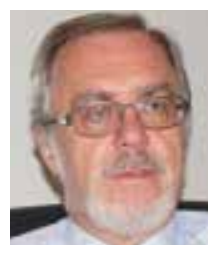

Prof. Miljenko Haiman, PhD. CE

University of Zagreb

Faculty of Architecture

miljenko.haiman@arhitekt.hr

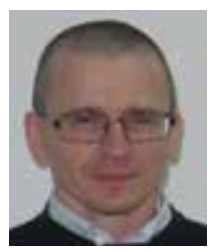

Prof. Mladen Meštrović, PhD. CE

University of Zagreb

Faculty of Civil Engineering

mestar@grad.hr

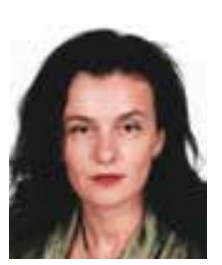

Prof. Vlatka Rajčić, PhD. CE

University of Zagreb

Faculty of Civil Engineering

vrajcic@grad.hr
Original scientific paper

\author{
Krunoslav Pavković, Miljenko Haiman, Mladen Meštrović, Vlatka Rajčić
}

\section{Truss girder joint with a large diameter mechanical fastener}

A joint with a large diameter fastener for connecting large span truss girder nodes is presented in the paper. The joint strength and slip modulus were analysed by means of experimental testing and the finite element method. The experimental testing was conducted on four truss girders with the proposed joint. The nonlinear truss girder model analysis, was conducted using the Abaqus/CAE software with the UMAT subroutine. The results obtained and analysed according to EN 21512, show that the proposed joint has a large strength and slip modulus, and that it can be used for large-span truss girders. The results also show that the equation for embedding compression strength according to EC5 should be modified.

Key words:
truss girder joint, non-linear analysis, large diameter fastener, glued-in rods, UMAT subroutine

Krunoslav Pavković, Miljenko Haiman, Mladen Meštrović, Vlatka Rajčić

Izvorni znanstveni rad

\section{Rješenje čvora rešetke spajalom velikog promjera}

Uraduje prikazan priključak spajalom velikog promjerazačvorove rešetkastih nosača velikih raspona. Eksperimentalnim istraživanjima i metodom konačnih elemenata provedenaje analiza otpornostii modula popustljivosti priključka. Eksperimentalna ispitivanja provedena su načetiri rešetkasta nosača spredloženim priključkom. U programskom paketu Abaqus/CAEsUMAT podrutinom, prikazanaje nelinearna analiza modela rešetke. Dobiveni rezultati prikazani u radu obradeni su prema EN 12512 , a pokazuju da predloženi priključak ima veliku otpornost i modul popustljivosti, primjenjiv za rešetke velikih raspona te da izraz dan u EC5 za karakteristični pritisak po omotaču rupe treba mijenjati.

Ključne riječi:

čvor rešetke, nelinearna analiza, spajalo velikog promjera, ulijepljene šipke, UMAT podrutina

Wissenschaftlicher Originalbeitrag

Krunoslav Pavković, Miljenko Haiman, Mladen Meštrović, Vlatka Rajčić

\section{Fachwerkträgerknoten mit Befestigungselementen großen Durchmessers}

Fachwerkträgerknoten mit Befestigungselementen großen Durchmessers Zusammenfassung In dieser Arbeit ist ein Knotenpunkt mit Befestigungselementen großen Durchmessers für Fachwerkträger bedeutender Spannweiten dargestellt. Festigkeit und Steifigkeit der Verbindung sind durch experimentelle Versuche und numerische FEM-Analysen ermittelt. Die Versuche sind an vier Trägern mit der vorgeschlagenen Verbindung abgeschlossen, während nichtlineare Analysen mit dem Programm Abaqus/CAE im UMAT Unterprogramm durchgeführt sind. Die erhaltenen Resultate zeigen, dass der Knoten ausreichende Festigkeit und Steifigkeit vorweist und für Träger großer Spannweiten angewandt werden kann. Außerdem wird auf die notwendige Modifizierung der Gleichung für Einbettungsdruck nach EC5 hingewiesen.

Schlüsselwörter:

eingeklebte Stäbe, Verbindung großen Durchmessers, nichtlineare Analyse, Fachwerkträgerknoten, UMAT Unterpogramm 


\section{Introduction}

In the design of large-span structures, the truss girder system, due to its small consumption of material and simplicity, is a logical and economically more cost-effective system, when compared to glulam girders. However, timber truss girders are very rarely used in our conditions for crossing large spans, i.e. the alternative solution involving the use of glulam girders is almost always adopted. Main reasons for such situation include the problem of truss node solving, wood industry lobby, and the negative attitude of architects toward truss girders. The usual and most frequently used solution for connecting timber truss girders is the connection by steel node plates and mechanical fasteners, which requires a large truss girder element area to adequately transfer force to the node plates and to ensure sufficient ductility. This frequently results in a bigger size of truss elements so that an appropriate number of fasteners can be distributed along an appropriate area, which leads to a greater consumption in wood and steel, and the structure becomes economically inefficient. Some other reasons why truss girders are avoided for crossing large spans include: reduced fire resistance at joints, and difficulties with the precamber, which is indispensable in structural systems which are exceeding 30,0 $\mathrm{m}$ in span.

In response to the belief that it is easier to use more than $50 \%$ of additional laminated timber for a glulam girder, rather than to solve the truss girders joints and fire-resistance problems, various possibilities have been investigated to see whether the situation can be changed through introduction of new connection systems. The objective of this paper is to find an appropriate solution for joints of large span trusses in order to enable fast assembly, proper definition of precamber during assembly, and a greater fire resistance. In this respect, it should be noted that an another solution based on a large diameter mechanical fastener, currently at the research stage, has been developed by SP-Trätek, Boras, Sweden [1]. The authors of this concept also consider that presentday solutions are overly complicated and costly, and that a new solution applicable to large-span trusses should be developed.

\subsection{Concept of the joint}

The concept of the joint studied in this paper is presented in Figure 1. It has been conceived through the use of a large-diameter fastener. The timber element into which the force is introduced (truss girder cord) is $210.0 \mathrm{~mm}$ in width, cf. Figure 1, but its width is defined based on the required truss girder cord resistance. The truss girder cord is conceived in such a way that its width can easily be changed via the number of lamellas depending on the required resistance, while the height is defined based on the width of lamellas.

The main connection element is a large-diameter mechanical fastener whose diameter is defined depending on the required resistance of the joint. It is installed in the hole drilled in the zone perpendicular to the element axis. Bolts are connection elements that link the fasteners with the element that introduces the force into the joint, and the diameter and number of bolts depends on the size of the force to be transfer by the joint.
The second half of the joint consists of an element that introduces the force into the joint. The introduction of the force into the joint can be solved via a timber element with a glued-in rod (as shown in Figure 1) [2], or directly by steel rod. The end of the rod (regardless of whether it is glued-in or independent) is inserted into the connection bush.

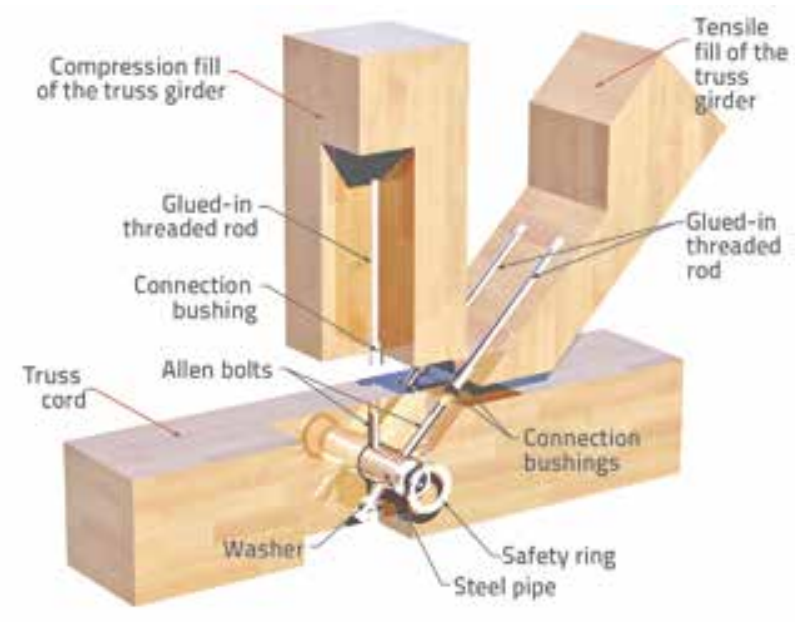

Figure 1. View of the truss joint

\subsection{Ductility, yield force and resistance of joint}

Ductility is a material property which indicates the level of material deformation in a plastic region prior to failure. It may rightfully be stated that it is an indispensable property of structures situated in seismically active areas. The ductility $(D)$ is expressed as the ratio of slip at yield force $\left(\delta_{y}\right)$ and max. force $\left(\delta_{\max }\right)[3]$ :

$D=\frac{\delta_{\max }}{\delta_{y}}$

When subjected to earthquake load, timber structures have to exhibit a sufficient level of ductility, so that the deformation in the plastic region would lead to the dissipation of energy in the static system.

CEN (European Committee for Standardisation) defines the test protocol for determining mechanical properties of connections/joints in timber structures through the following standards:

- for testing joints by static load EN 26891

- for testing joints by cyclic load EN 12512

However, these standards do not provide specific guidelines for determining ductility of joints subjected to static load [4]. As the joint subjected to static load is being tested, guidelines given in EN 12512 will be used for the determination of ductility.

Each joint has the following significant properties: initial joint slip modulus $K_{u}$ and joint slip modulus $K_{s}$. The slip modulus can be determined from the line defined with $10 \%$ and $40 \%$ of the maximum load, and corresponding slips at the $10 \%$ of 
the maximum load $\left(\delta_{0,1}\right)$ and $40 \%$ of the maximum load $\left(\delta_{0,4}\right)$, according to the following expression:

$K_{s}=\frac{0,4 \cdot F_{\max }-0,1 \cdot F_{\max }}{\delta_{0,4}-\delta_{0,1}}$

The initial joint slip modulus is determined from the inclination of line defined with the initial slip and slip at the load of $40 \%$ of the maximum load $F_{\max }\left(\delta_{0,4}\right)$. The difference between these two slip modulus is determined by unrecoverable deformations caused by beading of a fastener.

As in this case we are dealing with the fastener characterized by a large diameter, the relevant failure mode occurs after compressive strength exceeds embedment strength of the timber element. At that, the fastener remains undeformed. The design resistance $\left(R_{d}\right)$ for the embedment strength is given by the expression [5]:

$R_{d}=f_{h, a, d} \cdot t \cdot d$

where:

$f_{h, \alpha, d}$ - design embedment strength, for the load under the angle $\alpha$ with respect to grain,

$t \quad$ - is the thickness of the timber element for which the design resistance is determined,

$d \quad$ - is the diameter of the fastener.

The typical fastener embedment strength resistance is determined via experimental testing in accordance with EN 383 [6]. According to this standard, the characteristic embedment strength is obtained by driving the fastener of a specified diameter into a timber element in which the hole of an appropriate diameter is previously made. The fastener is inserted at a specified angle with respect to the grain, and the characteristic embedment force is obtained from the load $\left(F_{\max , 5}\right)$ which corresponds to a $5,0 \mathrm{~mm}$ slip value.

\section{Preparations for experimental study}

\subsection{Geometry and truss girder materials used in experimental study}

In the scope of this experimental study, four truss girder models were made using the new concept of the joint. They measure $6.0 \mathrm{~m}$ in axial span, with $2.0 \mathrm{~m}$ of axial distance between cords. Trusses are made with three cells, i.e. with four vertical compression web elements and tension web elements in the first and the last cell (Figure 2).

Truss girder elements were made of lamellas $42.0 \mathrm{~mm}$ in thickness, and each element consisted of five lamellas which, after planing, resulted in elements with the cross section measuring $21.0 \times 20.0$ [cm]. The melamine glue "Casco adhesives MUF system 1247/2526", manufactured in Casco Adhesives AB, Stockholm, Sweden, was used to glue the lamellas. According to mechanical properties of the timber used in lamellas production, the produced laminated elements can be classified as GL24h according to the EC5 standard.

To gain insight into the entire concept of this joint, glued-in rods, with the gluing-in depth of $35.0 \mathrm{~cm}$, were installed in to vertical compression web elements of the truss girder. A hole with the diameter exceeding by $2.0 \mathrm{~mm}$ the nominal diameter of the threaded rod was drilled in the centre of the timber element, as shown in paper [7]. Threaded rods quality grade 8.8 were selected, and the epoxy universal glue manufactured by KGK d.o.o., Karlovac, was used for the gluing. The glue is marketed under the commercial name "Epocon 88".

The quality of the materials used for steel elements was selected based on stresses obtained by preliminary finite element models (FEM). The steel quality $42 \mathrm{CrMo} 4 \mathrm{f}_{\mathrm{u}}=1600$ $\mathrm{N} / \mathrm{mm}^{2}$ according to EN-10027-1 was selected for the fabrication of washers, connection pipe, and fasteners. The steel quality S235JRCu according to EN 10027-1 was used for connection elements that are less exposed to stresses (rings). Allen bolts DIN 912, steel quality 12.9, were used for bolts in connections, while two bolts type M20, quality 12.9, were used for introducing force into the connection from steel diagonals. One bolt type M12, quality 12.9, was used to ensure structural connection between the vertical and the truss girder cord.

Steel rods $22.0 \mathrm{~mm}$ in diameter were used for tensile diagonals instead of timber elements with glued-in rods, as shown in Figure 1. The reason why timber diagonals were replaced with steel ones lies in greater simplicity of measurement, easier control of stress in steel diagonals, and smaller manufacturing price of rods for experimental testing. Tensile diagonals were made of steel quality $42 \mathrm{CrMo}_{\mathrm{f}} \mathrm{f}_{\mathrm{u}}=1600 \mathrm{~N} / \mathrm{mm}^{2}$.

\subsection{Experimental testing procedure}

The girder supportes were provided by steel plates 210 x 200 [mm], positioned on $600 \mathrm{~cm}$ axially spaced distance. These steel plates were laid on steel sections rounded on top and, in this way, hinged supports were simulated. During the testing, the top cored of the truss girder was laterally supported by a structure composed of steel pipes (Figure 2), to prevent loss of global stability of the girder.

The testing procedure consisted of applying concentrated load in each third of the span, with a controlled constant load rate. The load was applied by two hydraulic jacks connected to one another, so that the pressure in both jacks was always the same. Truss girders were tested with the relaxation at total load of $60,0 \mathrm{kN}$, after the force was brought down to $20,0 \mathrm{kN}$, load was continuously increased until truss girder failure.

The applied load was measured via measuring devices placed between hydraulic cylinders and the top cord of the truss girder, as shown in Figure 2. During the testing, stresses in the steel diagonals were measured via tensometers marked T1 to T4. Measuring of truss girder deformation was conducted in the thirds of the span using measuring devices marked L500/03 and L500/04. Local deformation was measured for joints situated at 
the bottom cord of the truss girder, i.e. the displacement of the bolts end which are entering into the diagonals was measured with respect to the point situated in the bolt axis $100 \mathrm{~mm}$ away from the centre of the fastener. The total of four measuring devices marked L100/02 to L100/05 were placed on two measured joints at the bottom cord of the truss girder, i.e. one measuring device per bolt by which the force from the tensile diagonal is introduced into the joint. Deformation and displacement were monitored and records at one second intervals via personal computer.

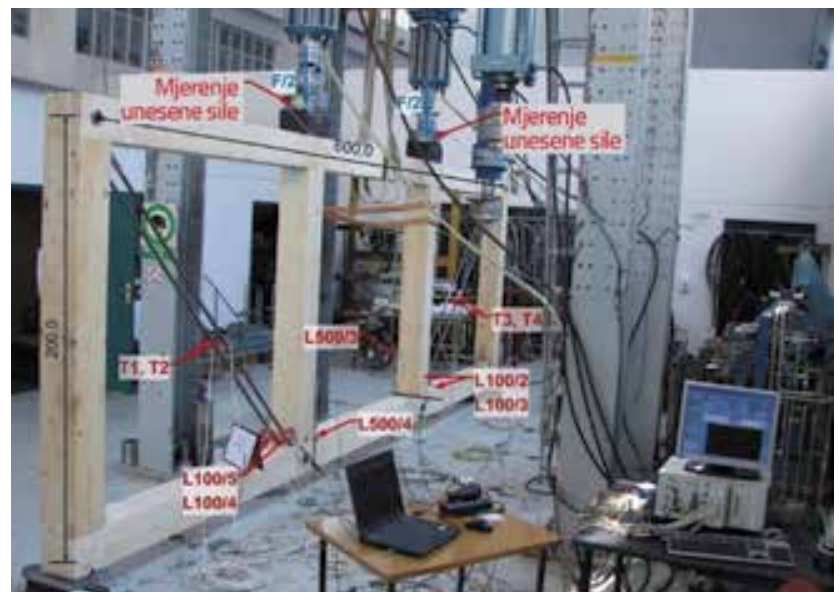

Figure 2. Experimental testing of trusses

It should be noted that, during truss girder assembly in the laboratory, all bolts at joints were mounted using the controlled force of $4.5 \mathrm{kN}$, i.e. the fastening moment of 17.0 $\mathrm{Nm}$. This bolt tightening resulted in a $12.0 \mathrm{~mm}$ precamber at the centre of the span.
During the testing, the moisture of truss girder elements varied from 11.8 to 13.7 percent. The temperature in the room during the testing of the second truss girder was $30^{\circ} \mathrm{C}$, and during other tests was $28^{\circ} \mathrm{C}$.

\subsection{Analysis by finite element method}

\subsubsection{Geometry and materials for numerical modelling of the truss}

The FEM of the truss girder was made using the program package Abaqus/CAE ver. 6.10. The nonlinear analysis was conducted. The FEM geometry fully coincided with the truss girder geometry used in laboratory testing. Volume finite elements C3D3, defined with six nodes [8], were used for modelling of timber elements. All steel elements of the connection, as well as tensile ties, were modelled with the volume finite elements C3D8 defined with eight nodes. The FEM of the truss girder was fully defined with 168,454 finite elements and, considering the great number of finite elements, only one half of the truss girder was modelled with boundary conditions which simulate symmetry, as shown in Figure 3.

The load was modelled in two steps; in the first one the bolt and tie prestressing load were applied, which corresponded to the methodology used in the experimental testing and in the second step external load was applied on upper cord of truss girder. As this was a nonlinear analysis with geometrical and material nonlinearity, the load values were set related to time. The bolt prestressing load was defined as "bolt load", and increasing of load was related to time - amplitude curve as is presented in Figure 3. A linear increase of prestressing load was modelled in each bolt in the time period varying from $0 \mathrm{t}$ to $10 \mathrm{t}$. After full prestressing

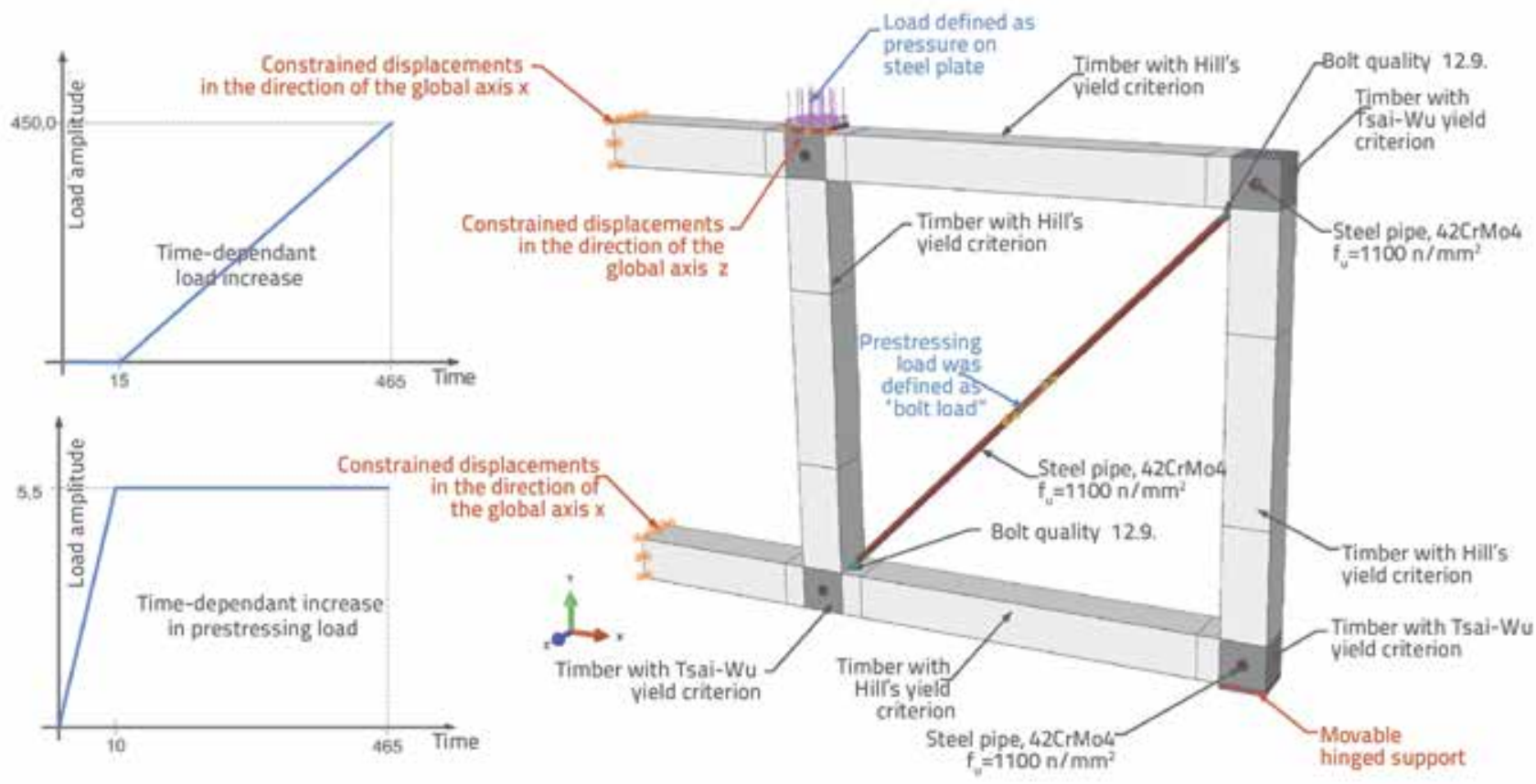

Figure 3. Presentation of FEM with boundary conditions and applied load 
load was applied the load continued with the second step in which the external load was applied onto the truss girder set as the pressure on the steel plate above the compression web elements, as shown in Figure 3. The load increasing rate was set by a time -dependent amplitude. The graphical presentation of time-related load amplitudes is given for both loading steps in Figure 3.

Modelling of mechanical properties of steel parts was conducted elasto - plastic according to diagrams presented in Figure 4. The plastic region was modelled across 15 points which were obtained as an average value from actual stress strain diagram, while elastic modulus and yield strength were set according to values given in Table 1. Bolts were modelled bi-linearly with the yield strength and elastic modulus as given in Table 1, while the tangential elastic modulus was defined as being equal to 10 percent of the elastic modulus.

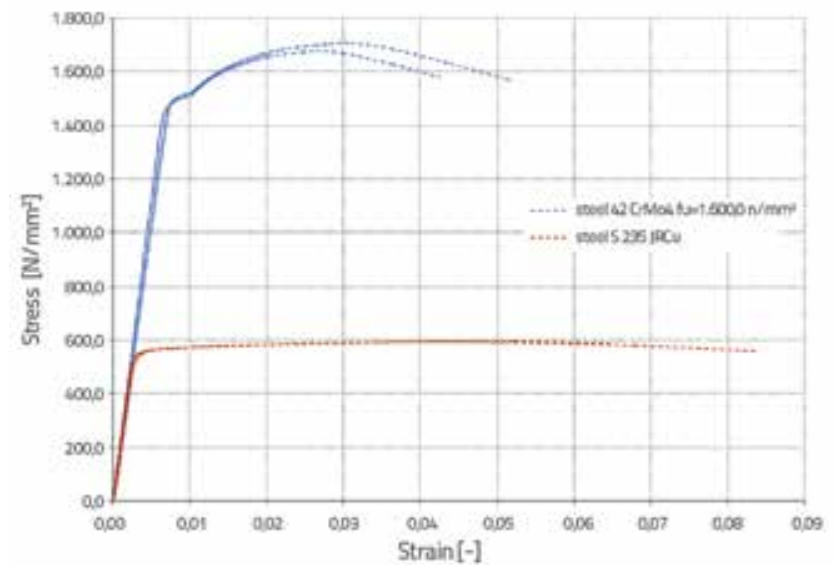

Figure 4. Actual stress - strain steel diagrams used for connection elements

Mechanical properties of timber were modelled elasto - plastic and orthotropic. As, due to its orthotropic nature, modelling

Table 1. Mechanical properties of materials

Mech. properties

\begin{tabular}{|c|c|c|c|c|c|}
\hline Mech. properties & $\begin{array}{l}\text { Modulus of elasticity } \\
\qquad\left[\mathrm{N} / \mathrm{mm}^{2}\right]\end{array}$ & $\begin{array}{l}\text { Shear modulus } \\
\qquad\left[\mathrm{N} / \mathrm{mm}^{2}\right]\end{array}$ & $\begin{array}{l}\text { Poisson } \\
\text { ratio }\end{array}$ & $\begin{array}{l}\text { Compressive strength } \\
\qquad\left[\mathrm{N} / \mathrm{mm}^{2}\right]\end{array}$ & $\begin{array}{c}\text { Tensile strength } \\
{\left[\mathrm{N} / \mathrm{mm}^{2}\right]}\end{array}$ \\
\hline \multirow{4}{*}{$\begin{array}{l}\text { Glulam timber } \\
\text { GL } 24 \mathrm{~h}\end{array}$} & $E_{L}=11.314,0$ & $\mathrm{G}_{\mathrm{LR}}=677,0$ & $v_{L R}=0,41$ & $\mathrm{f}_{\mathrm{u}, \mathrm{L}}^{\mathrm{c}}=-28,16$ & $\mathrm{ft}_{\mathrm{u}, \mathrm{L}}^{\mathrm{t}}=29,82$ \\
\hline & $E_{T}=469,0$ & $G_{R T}=50,0$ & $v_{R T}=0,517$ & $\mathrm{f}_{\mathrm{u}, \mathrm{T}}^{\mathrm{c}}=-3,30 \mathrm{~N}$ & $\mathrm{ft}_{\mathrm{u}, \mathrm{T}}^{\mathrm{t}}=0,38$ \\
\hline & $E_{R}=746,0$ & $\mathrm{G}_{\mathrm{LT}}=658,0$ & $v_{L T}=0,52$ & $\mathrm{f}_{\mathrm{u}, \mathrm{R}}^{\mathrm{c}}=-3,30$ & $\mathrm{f}_{\mathrm{u}, \mathrm{R}}^{\mathrm{t}}=0,38$ \\
\hline & - & - & - & $f_{u, S}=3,3$ & $f_{u, S}=3,3$ \\
\hline Steel 42CrMo4 & $E=200.054,0$ & $G=76.944,0$ & $v=0,3$ & $f_{y}=1.425,0$ & $f_{u}=1.635,0$ \\
\hline Steel S 235JRCu & $E=219.169,0$ & $G=84.296,0$ & $v=0,3$ & $f_{y}=535,0$ & $f_{u}=595,8$ \\
\hline $\begin{array}{c}\text { Bolt quality } 12.9 . \\
\text { (modelled bi-linearly) }\end{array}$ & $E=210.000,0$ & $\mathrm{G}=84.000,0$ & $v=0,3$ & $f_{y}=1.080,0$ & - \\
\hline
\end{tabular}

procedures is much more complex than steel modelling and hence impracticable with the basic program package Abaqus/ CAE, the UMAT subroutine had to be used to define the timber. Two timber yield criteria were defined via this subroutine: the Tsai-Wu criterion for the connection zone, and a yield criterion derivative from the Hill's yield criterion for other parts of the timber. The coordinate system by which mechanical properties of timber were described is marked with $\mathrm{R}$, $\mathrm{T}$ and $L$ axes (which stands for radial, transverse and longitudinal directions, respectivelly). Elastic modulus and shear modulus for each direction were obtained as average values of timber having the bulk density $\left(\rho=443,47 \mathrm{~kg} / \mathrm{m}^{3}\right)$ similar to the timber used in truss girger manufacture, as found in available literature [9-4]. The values from these sources are presented in Table 1.

Main wood strength values for each direction were adopted from literature $[15,16]$. The testing conducted in the selected literature was made on the same timber quality, the bulk density of wood was almost identical, and the wood type and weather conditions in which the tree has grown are quite similar.

\subsubsection{UMAT subroutine and wood yield criteria}

The UMAT subroutine was used for the definition of yield criteria and mechanical properties of wood. Prior to its incorporation in the program package ABAQUS as the "userdefined material", the UMAT subroutine had to be written in the programming language FORTRAN [17]. One of main problems encountered during FEM of timber, resulting from the orthotropic nature and in homogeneity of this material, lies in the definition of yield criteria. In this respect, a derivative of the Hill's criterion for homogeneous materials was used in the UMAT subroutine as the basic yield criterion.

The Hill's yield criterion for orthotropic homogeneous materials [18] is expressed as: 


$$
\left\{\begin{array}{l}
A\left(\sigma_{R}-\sigma_{T}\right)^{2}+B\left(\sigma_{T}-\sigma_{L}\right)^{2}+C\left(\sigma_{L}-\sigma_{R}\right)^{2}+2 \cdot D \cdot \tau_{R T}^{2}+2 \cdot E \cdot \tau_{T L}^{2}+2 \cdot F \cdot \tau_{L R}^{2}=1 \\
\boldsymbol{A}=\frac{1}{2}\left[\frac{1}{\left(f_{u, R}\right)^{2}}+\frac{1}{\left(f_{u, T}\right)^{2}}-\frac{1}{\left(f_{u, L}\right)^{2}}\right] ; B=\frac{1}{2}\left[\frac{1}{\left(f_{u, T}\right)^{2}}+\frac{1}{\left(f_{u, L}\right)^{2}}-\frac{1}{\left(f_{u, R}\right)^{2}}\right] \\
C=\frac{1}{2}\left[\frac{1}{\left(f_{u, L}\right)^{2}}+\frac{1}{\left(f_{u, R}\right)^{2}}-\frac{1}{\left(f_{u, T}\right)^{2}}\right] ; D=\frac{1}{2 \cdot\left(f_{u, R T}\right)^{2}} ; \\
E=\frac{1}{2 \cdot\left(f_{u, T L}\right)^{2}} ; F=\frac{1}{2 \cdot\left(f_{u, L R}\right)^{2}}
\end{array}\right.
$$

where $\sigma$ is the normal stress, $\tau$ is the shear stress, and $f_{u}$ is the stress in the corresponding direction. As the above expression does not take into account the brittle failure of wood in tension, i.e. if the above condition is not satisfied, mechanical properties for all directions are calculated in a plastic area. For this reason, the above condition does not give a sufficiently accurate description of the wood behaviour in compression, and its brittle failure. The behaviour would be much more accurate if the expression is separated, and if a separate criterion is set for each direction $[19,20]$ :

$$
\frac{\sigma_{L}^{2}}{f_{u, L}^{t}{ }^{2}}+\frac{2 \cdot \tau_{R T}^{2}}{f_{u, S h}^{2}}=1 ; \quad \frac{\sigma_{R}^{2}}{f_{u, R}^{t}{ }^{2}}+\frac{2 \cdot \tau_{L R}^{2}}{f_{u, S h}^{2}}=1 ; \quad \frac{\sigma_{T}^{2}}{f_{u, T}^{t}{ }^{2}}+\frac{2 \cdot \tau_{T L}^{2}}{f_{u, S h}^{2}}=1
$$

where $f_{u}^{t}$ is the tensile strength and $f_{u, S h}$ is the shear strength equal for each directions. This criterion for tension takes into account interaction between the normal stress and shear stress for a given plane, and their separation ensures independence of three mutually orthogonal planes. The criterion of yield in compression is defined via a simple maximum stress criterion. If maximum stresses exceed the yield limit for one direction, then a plastic region is assumed for all three directions.

$$
\frac{\sigma_{L}}{f_{u, L}^{c}}=1 ; \quad \frac{\sigma_{R}}{f_{u, R}^{c}}=1 ; \quad \frac{\sigma_{T}}{f_{u, T}^{c}}=1
$$

where $f_{u}^{c}$ is the compressive strength. It should be noted that there is a considerable similarity between the above yield criterion and the Hasin (1980) yield criterion [21], which is destined for materials with the pronounced difference in mechanical properties in the direction of fibres and perpendicular to these fibres.

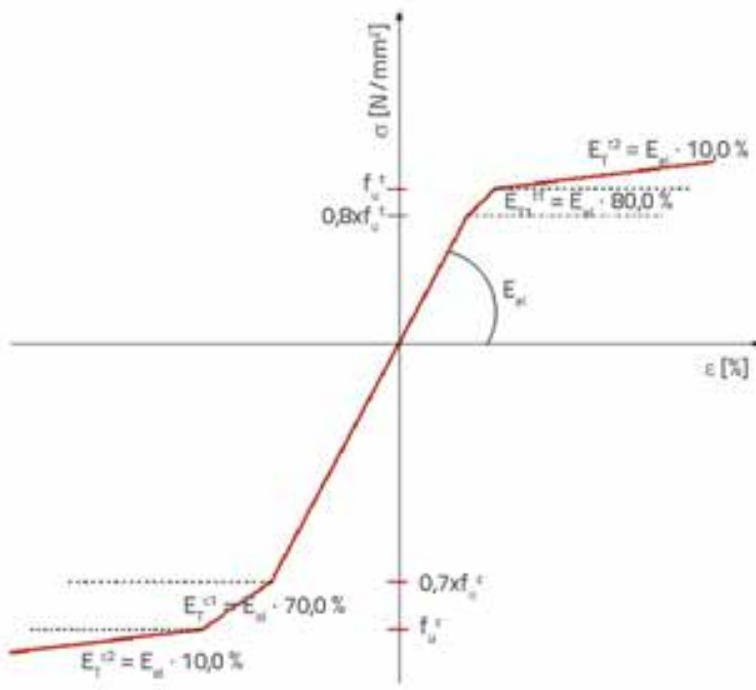

Figure 6. Stress - strain diagram for timber, Hill's yield criterion
The second timber yield criterion in the connection zone is the Tsai-Wu criterion, which is defined with:

$$
\begin{gathered}
F_{1} \sigma_{L}+F_{2} \sigma_{R}+F_{3} \sigma_{T}+2 F_{12} \sigma_{L} \sigma_{R}+2 F_{13} \sigma_{L} \sigma_{T}+2 F_{23} \sigma_{T} \sigma_{R}+F_{11} \sigma_{L}^{2}+F_{22} \sigma_{R}^{2}+F_{33} \sigma_{T}^{2}+ \\
F_{44} \tau_{L R}^{2}+F_{55} \tau_{L T}^{2}+F_{66} \tau_{R T}^{2}=1
\end{gathered}
$$

If the values $F_{121} F_{13 \prime}, F_{23}$ are neglected because of the small influence, the expression (7) can be adopted in an abbreviated form:

$$
\left\{\begin{array}{l}
F_{1} \sigma_{L}+F_{2} \sigma_{R}+F_{3} \sigma_{T}+F_{11} \sigma_{L}^{2}+F_{22} \sigma_{R}^{2}+F_{33} \sigma_{T}^{2}+F_{44} \tau_{L R}^{2}+F_{55} \tau_{L T}^{2}+F_{66} \tau_{R T}^{2}=1 \\
F_{1}=\frac{1}{f_{u, L}^{t}-f_{u, L}^{c}} ; F_{2}=\frac{1}{f_{u, R}^{t}-f_{u, R}^{c}} ; F_{3}=\frac{1}{f_{u, T}^{t}-f_{u, T}^{c}} ; F_{11}=\frac{1}{f_{u, L}^{t} \cdot f_{u, L}^{c}} ; F_{22}=\frac{1}{f_{u, R}^{t} \cdot f_{u, R}^{c}} ; \\
F_{33}=\frac{1}{f_{u, T}^{t} \cdot f_{u, T}^{c}} ; F_{44}=F_{55}=F_{66}=\frac{1}{f_{u, S h}^{2}}
\end{array}\right.
$$

In order to obtain regions in the working diagram, the yield criterion presented in expression (8) is adopted in such a way that the first yield strength is defined if the expression reaches the value 0.0 , the second when the value of 0.7 is reached, and the third when the value of 1.0 is reached. This is presented graphically in Figure 5.

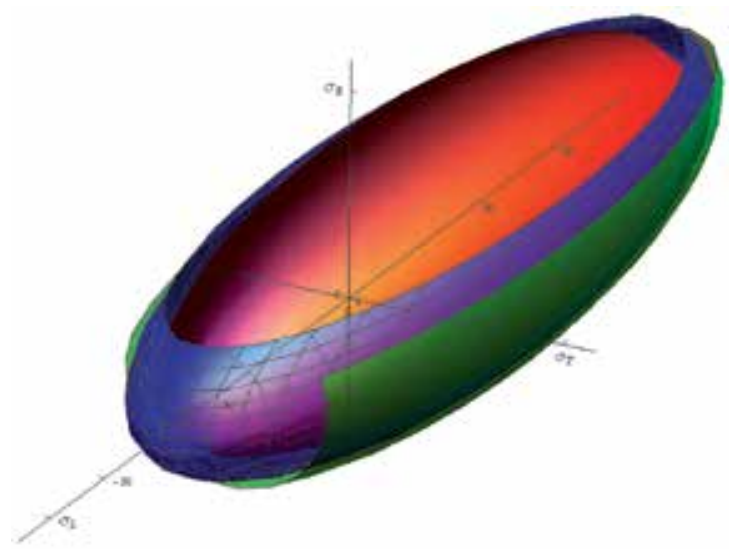

Figure 5. Tsai-Wu yield criterion

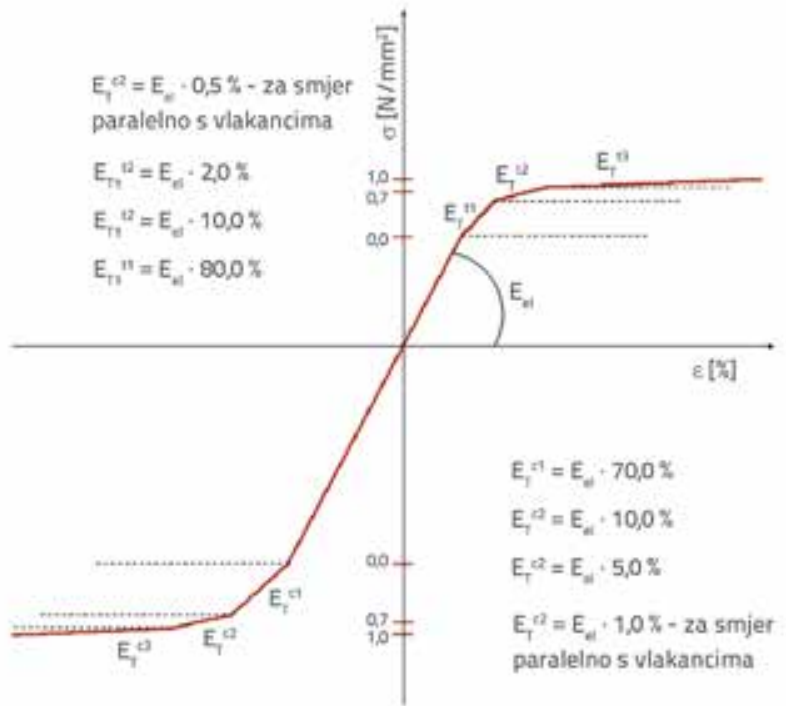

Figure 7. Stress - strain diagram for timber, Tsai-Wu yield criterion 
These yield criteria and their conditions are defined so as to obtain regions in the stress - strain diagram for timber, as shown in Figures 6 and 7.

\subsubsection{Finite element method in the UMAT subroutine}

After the yield criterion was defined, the subroutine for the elastic, orthotropic material was formulated by means of the finite element method. Due to complexity of the subroutine that would describe the elasto - plastic behaviour of materials, the formulation of finite elements was adopted for the elastic behaviour of materials. The modification made to the subroutine so that it can provide highly accurate results same as elasto- plastic analysis, is that the second (plastic) elastic modulus is adopted for the stresses if one of criteria is not met. Such a simplification is possible in this case because the load increasing rate is constant, and residual plastic deformations are not observed.

Elastic stresses according to the finite element method [22] are calculated according to the expression (9):

$\{\sigma\}^{t+1}=\{\sigma\}^{t}+[M]\{\varepsilon\}^{\Delta t}$

where:

$\{\sigma\}^{t+1}$ - stress vector in time $t+1$

$\{\sigma\}^{\mathrm{t}} \quad$ - stress vector in time $\mathrm{t}$

[M] - orthotropic matrix of elastic constants

$\{\varepsilon\}^{\beta^{\mathrm{t}}}$ - deformation vector in time $\mathrm{t}+1$

$[M]=\left[\begin{array}{cccccc}D_{\text {LLLL }} & D_{\text {LLRR }} & D_{\text {LLTT }} & 0 & 0 & 0 \\ & D_{\text {RRRR }} & D_{\text {RRTT }} & 0 & 0 & 0 \\ & & D_{\text {TITT }} & 0 & 0 & 0 \\ & & & D_{\text {LRLR }} & 0 & 0 \\ & \text { sim. } & & & D_{\text {LTLT }} & 0 \\ & & & & & D_{\text {RTRT }}\end{array}\right]$

$\{\varepsilon\}=\left\{\varepsilon_{\mathrm{L}} \varepsilon_{\mathrm{R}} \varepsilon_{\mathrm{T}} \gamma_{\mathrm{RT}} \gamma_{\mathrm{LT}} \gamma_{\mathrm{LR}}\right\}^{\mathrm{T}}$

$\{\sigma\}=\left\{\sigma_{\mathrm{L}} \sigma_{\mathrm{R}} \sigma_{\mathrm{T}} \tau_{\mathrm{RT}} \tau_{\mathrm{LT}} \tau_{\mathrm{LR}}\right\}^{\top}$

where $\varepsilon$ is the normal deformation, and $\gamma$ is the shear deformation.

Component matrices for elastic constants are calculated according to:

$D_{L L L L}=E_{L}\left(1-\left(v_{\mathrm{RT}} v_{\mathrm{TR}}\right)\right) \gamma$

$D_{R R R R}=E_{R}\left(1-\left(v_{\mathrm{LT}} v_{\mathrm{TL}}\right)\right) \gamma$

$D_{\text {TITT }}=E_{T}\left(1-\left(v_{\mathrm{LR}} v_{\mathrm{RL}}\right)\right) \gamma$

$D_{L L R R}=D_{R R L L}=E_{L}\left(v_{\mathrm{RL}}+\left(v_{\mathrm{TL}} v_{\mathrm{RT}}\right)\right) \gamma$

$D_{L L T T}=D_{T L L L}=E_{L}\left(v_{\mathrm{RL}}+\left(v_{\mathrm{RL}} v_{\mathrm{TR}}\right)\right) \gamma$

$D_{R R T}=D_{T T R R}=E_{R}\left(v_{\mathrm{TR}}+\left(v_{\mathrm{LR}} v_{\mathrm{TL}}\right)\right) \gamma$

$D_{L R L R}=G_{L R}$

$D_{L T L T}=G_{L T}$

$D_{\text {RTRT }}=G_{R T}$

$\gamma=\frac{1}{1-v_{L R} v_{R L}-v_{R T} v_{T R}-v_{T L} v_{L T}-2 v_{R L} v_{T R} v_{L T}}$

\section{Analysis of results}

Stress - strain diagrams of connections were obtained from the data collected by stresses measurements in all four diagonals, and by measuring displacement of bolts that form an integral part of the connection. The applied load and the displacement of connection device was obtained for each connection through analysis of results, as shown in graph presented in Figure 8.

The yield force, slip modulus, and ductility of joints can be determined according to method $1 / 6$ from load - slip diagrams obtained from truss girder joints. In addition, as in these joints the failure principally occurs because the compressive embedment strength is exceeded. Embedment strength can be determined in accordance with EN 383 [6].

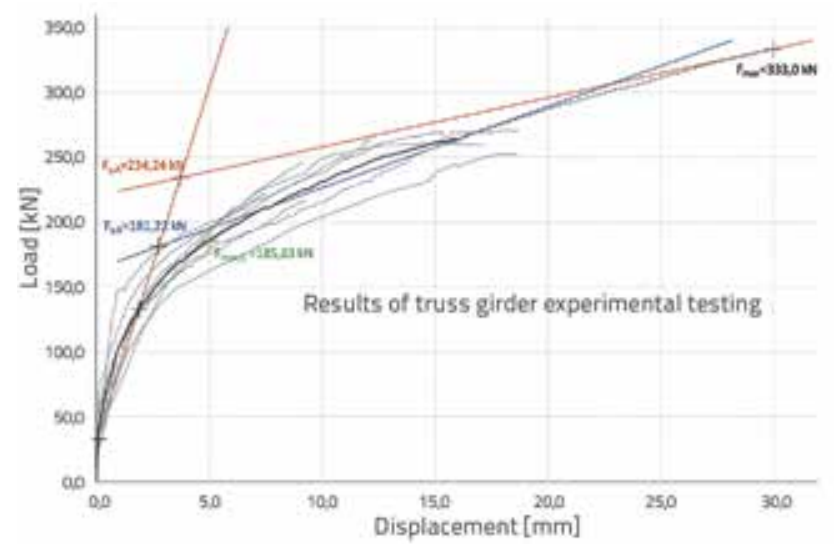

Figure 8. Average values of experimental results for truss girders

In order to avoid wrong definition of caracteristic values, the average value of all truss joint results was defined as shown in Figure 8 (black line). The maximum force according to EN 12512 was adopted as the smaller value of three conditions: maximum load at the moment of total joint failure, maximum load until the moment the $80 \%$ of load drop was registered, and maximum load at $30,0 \mathrm{~mm}$ slip value. In the analysis of results, the assumption of joint behaviour in plastic region until 30,0 $\mathrm{mm}$ slip value was added to the average value. In fact, the analysis of experimental tests revealed that it can be assumed with a great amount of certainty that the connection will attain $30,0 \mathrm{~mm}$ slip value before failure of any of its elements, or before load drop in the load - slip diagram.

It should be noted that the load for all joints, and for the average load value, was increased for $9,0 \mathrm{kN}$ in the graph given in Figure 8, which is the prestressing load aplied before the start of experimental testing.

Caracteristic load values were defined according to the graph given in Figure 8, and based on the maximum load defined according to the above described procedure. The failure load $F_{y}$ $=181,22 \mathrm{kN}$ and maximum load $F_{\text {max }}=234,24 \mathrm{kN}$ were obtained through analysis of results. In addition, the maximum force at 
$5.0 \mathrm{~mm}$ displacement is $F_{\max , 5}=185,63 \mathrm{kN}$, the slip modulus is $K_{s}=54,89 \mathrm{kN} / \mathrm{mm}$, while the ductility is $D=8,08$.

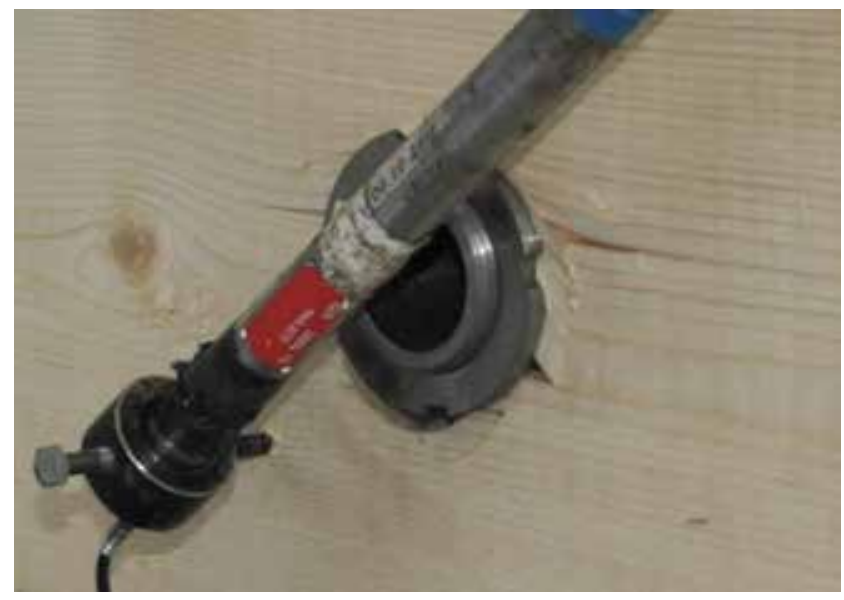

Figure 9. Deformation of central joint in the second truss

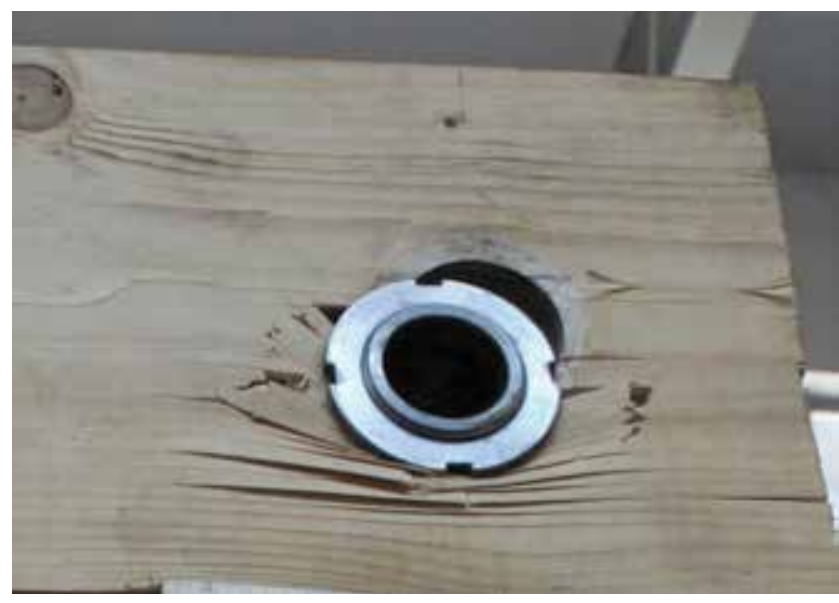

Figure 10. Deformation of edge joint in the second truss

Values recorded in each third of the locally reinforced truss girders, monitored by devices L500/4 and L500/3, are presented below.

Deformations obtained by FEM of the truss are presented in Figure 12 for the time when full bolt prestressing load is applied. Displacements obtained by FEM show maximum displacement of $12,50 \mathrm{~mm}$ at truss cord near boundary conditions. The displacements obtained by FEM show good correlation with the precamber obtained during preparation of truss girder for experimental testing.

FEM analysis of the truss girder model was conducted to the load of $410,0 \mathrm{kN}$. As these are very large deformations, especially in the connection zone, the convergence of analysis was interrupted due to excessive deformation of finite elements before the specified load of $450,0 \mathrm{kN}$ was reached. Displacements at the load of $410,0 \mathrm{kN}$ was presented in Figure 13. The entire load - slip diagram is presented, together with diagrams of experimental testing, in Figure 11 (red line).
Stress values obtained at the $410,0 \mathrm{kN}$ load are presented for the direction parallel to grain $\mathrm{S} 11$ in Figure 14, and perpendicular to grain S33 (tangential direction if related to truss girder model for experimental testing) in Figure 15. Stress values are presented in such a way that the legend is limited to the tensile strength and compression strength, so that the zones in which stress values exceed strength of the timber class GL $24 \mathrm{~h}$ can easier be identified.

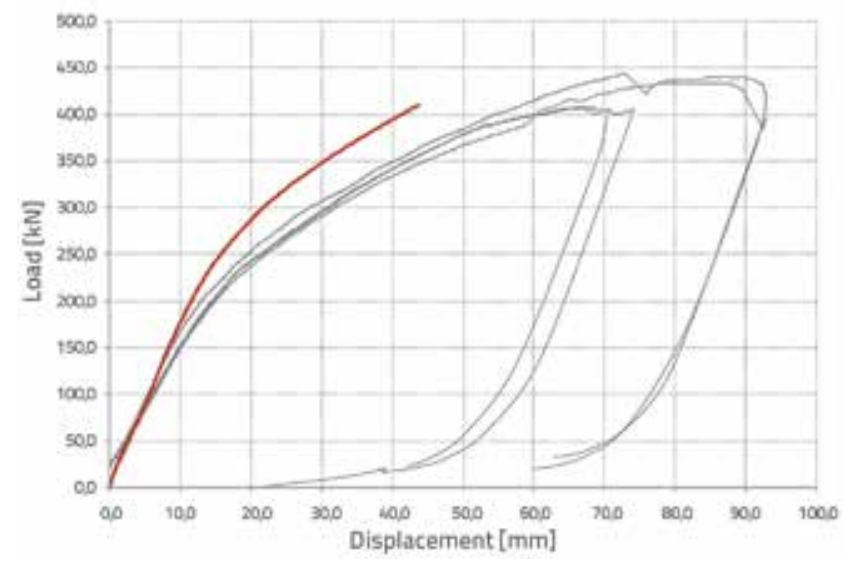

Figure 11. Displacements in each third of the truss girder as obtained by experimental testing and FEM

For stress values parallel to grain, it can be concluded that they do not exceed the timber strength in large areas, which is why they are not of big significance for the truss girder resistance and stiffness.

Significant stress values for the resistance of joints and truss girders were obtained in the S33 direction. As shown in Figure 13 , great zones in which stress exceed the strength in the direction perpendicular to grain appear in zones around the fasteners. This stress causes great slip of the joint, i.e. the steel pipe penetrates into the timber. A similar occurrence (pipe penetration) was noted during experimental testing. The greatest concentration of the stress that exceeds the strength was obtained in the connection (joint) above the hinged support. During experimental testing, a big penetration of steel support into the timber occurred at this very joint, and the laminas separated due to excessive compression perpendicular to the grain.

The characteristic embedment strength in the direction parallel to grain was derived based on experimental results. This strength value is presented in the graph (Figure 16) together with some other characteristic embedment strength proposed by other authors depending on the diameter of the fastener. It can be seen from the graph that the expression in EC5 has an excessive stress reduction with respect to the increase of the fastener diameter. Better design equations are presented by S. Franke and P. Quenneville [23], and K. Sawata and M. Yasumura [24]. 


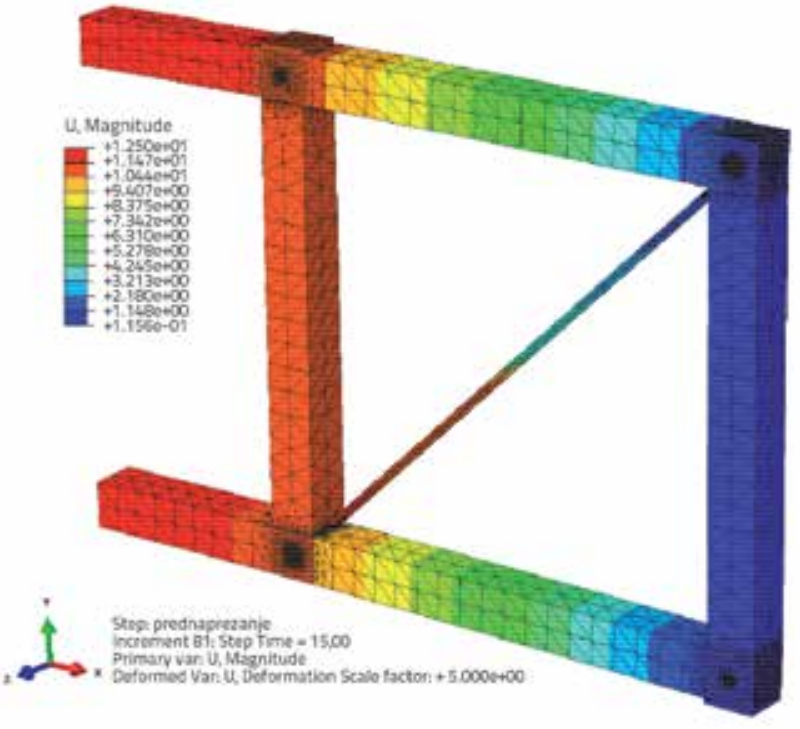

Figure 12. Truss girder displacements after prestressing

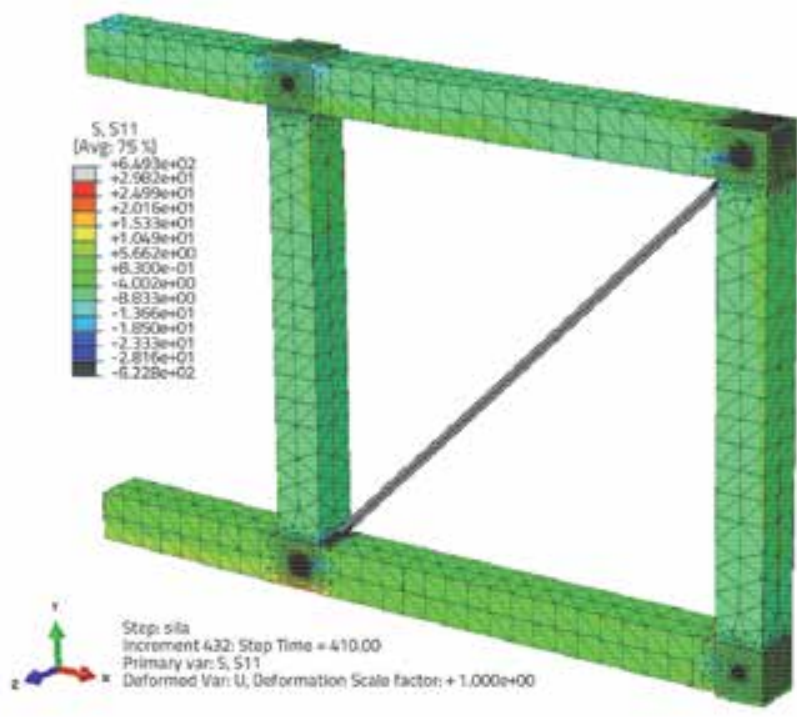

Figure 14. Stress in the S11 direction parallel to the fibres

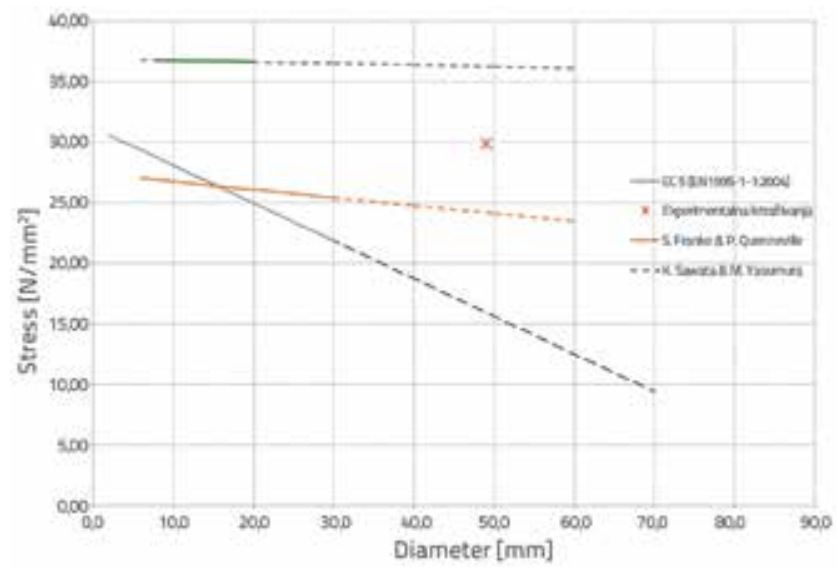

Figure 16. Comparison of characteristic embedment strength parallel to grain

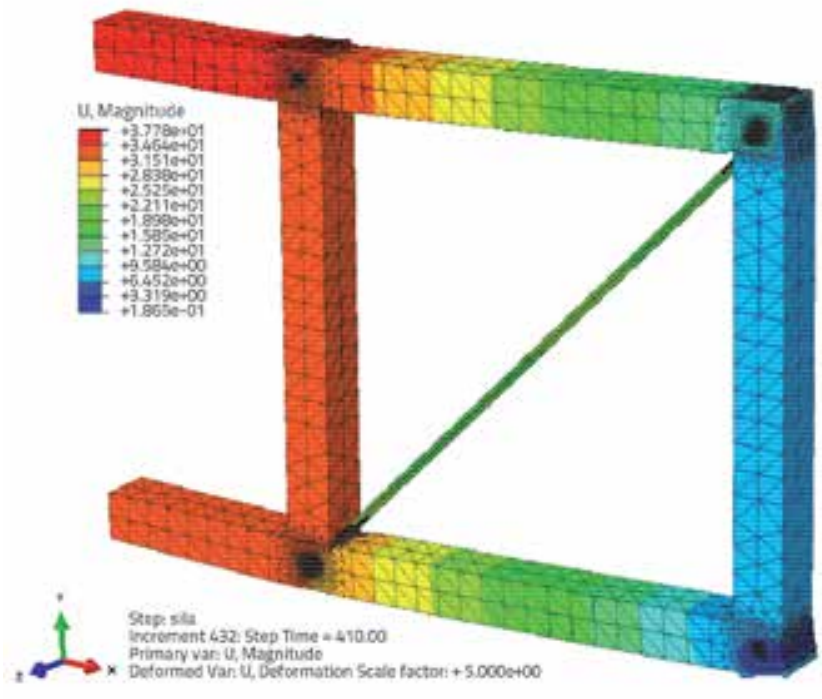

Figure 13. Truss girder displacements at the load of $410,0 \mathrm{kN}$

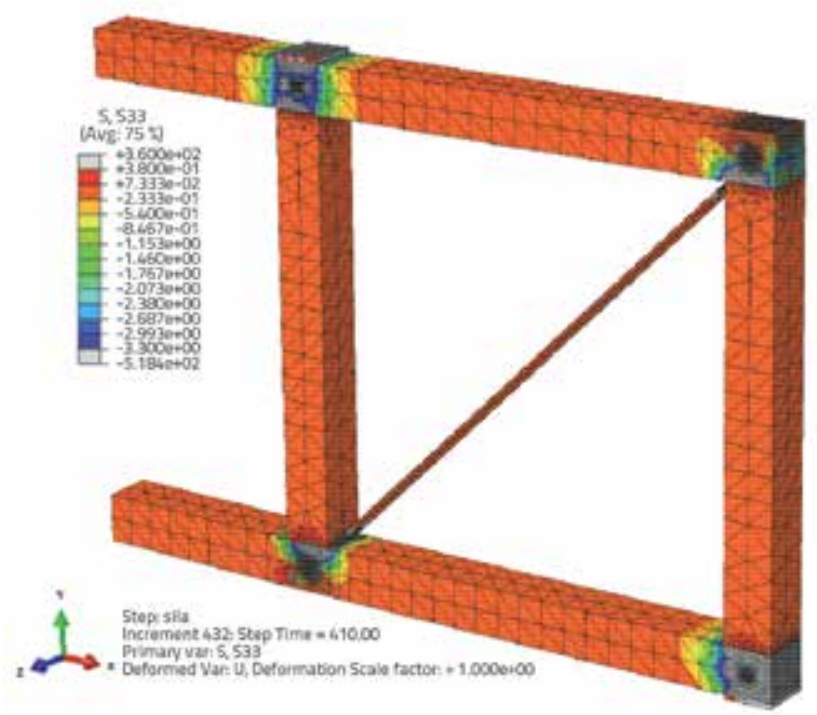

Figure 15. Stress in the S33 direction perpendicular to the fibres

\section{Conclusion}

The characteristic embedment strength in the direction parallel to grain as shown in graph form (Figure 16), was derived based on experimental tests results. It can be concluded that the expression given in regulations EC5 should be modified and extended to enable dimensioning of joints with fasteners that exceed $30 \mathrm{~mm}$ in diameter.

In addition, FEM based on the program package Abaqus/CAE and UMAT subroutine with the mentioned Hill and Tsai-Wu yield criterion, show a very good correspondence overlapping with experimental results. Such complex FEM analyses enable to conduct joint parametric analyses in the scope of which the behaviour of fasteners with other diameters could be monitored. 
Finally, it can be concluded from first results presented in this paper that, in addition to further research regarding large-diameter fasteners, this type of joint can also be used to design truss girders from 30.0 to $50.0 \mathrm{~m}$ in span. This joint has been registered and protected with the State International Property Office of the Republic of Croatia, under No. P20120249A.

\section{REFERENCES}

[1] Kobel, P.: Modelling of Strengthened Connections for Large Span Truss Structures, in Department of Structural Engineering, 2011, Lund Institute of Technology: Sweden.

[2] Rajčić, V., Bjelanović, A., Rak, M.: Nosivost ulijepljenih navijenih čeličnih šipki u elementima od hrastovine. Građevinar, 2004. 56(3), p. 155-161.

[3] Joachim, H., Schadle, P.: Ductility aspects of reinforced and nonreinforced timber joints. Engineering Structures 2011, 33(11), p. 3018-3026.

[4] Piazza, M., Polastri, A., Tomasi, R.: Ductility of timber joints under static and cyclic loads. Structures and Buildings, 2011. 164(sb2), p. 79-90.

[5] CEN, E.C.f.S., Eurocode 5: Design of timber structures. EN19951-1, Part 1-1: General - Common rules and rules for buildings, 2004, Brussels: European committee for standardization.

[6] CEN, E.C.f.S., EN 383:2007. Timber Structures-Test methodsDetermination of embedment strength and foundation values for dowel type fasteners, 2007.

[7] Tlustochowicz, G., Serrano, E., Steiger, R.: State-of-the-art review on timber connections with glued-in steel rods. Materials and Structures, 2011. 44(5), p. 997-1020.

[8] Abaqus, Analysis User's Manual, in Volume IV: Elamants6.10.

[9] Bodig, J., Jayne, A.B.: Mechanics of Wood and Wood Composites 1982, New York: Van Nostrand Reinhold Company. p 712.

[10] Carrington, H.: The elastic constants of spruce. Philosophical Magazine, 1923. 45, p. 1055-1057.

[11] Jenkin, C.F.: Report on materials used in the construction of aircraft and aircraft engines, 1920, Her Majesty's Stationery Office: London. p. 95-131.

[12] Doyle, D.V., Drow, J.T., McBurney, R.S.: Elastic properties of wood. The Young's Moduli, Moduli of Rigidity, and Poisson's Ratios of Balsa and Quipo (1528). The Elastic Properties of Wood. The Moduli of Rigidity of Sitka Spruce and heir Relations to Moisture Content (1528-A). The Elastic roperties of Wood. Young's Moduli and Poisson's Ratio of Sitka Spruce and Their Relations to Moisture Content (1528-B). Forest Products Laboratory, 1945. $41,15,38$

\section{Acknowledgement}

Authors are thankful to the Polytechnic of Zagreb on their financial support without which the testing presented in the paper would not be possible, and for the material support and services provided by the following companies: Hoja d.d., Slovenia, and Stolarija Grčić, Karlovac.

[13] CEN, E.C.f.S., EN 1194:1999Timber structures - Glued laminated timber - Strength classes and determination of characteristic values, 1999.

[14] CEN, E.C.f.S., EN 338:2003 Structural timber - Strength classes, 2003.

[15] Haiman, M.: Analiza sigurnosti lameliranih nosača, Građevinski fakultet, 2001, Sveučilište u Zagrebu: Zagreb.

[16] Čizmar, D.: Robusnost nosivih sustava drvenih rešetkastih nosača, Građevinski fakultet, 2012, Sveučilište u Zagrebu: Zagreb.

[17] Abaqus, User Subroutines, in Reference Manual6.10.

[18] Hill, R.: A Theory of the yielding and plastic flow of anisotropic metals. Proceedings the royal society A, 1984. 193, p. 281-297.

[19] Xu, B.H., et al.: Numerical and experimental analyses of multipledowel steel-to-timber joints in tension perpendicular to grain. Engineering Structures, 2009. 31, p. 2357-2367.

[20] Xu, B.H., Bouchair, A., Taazount, M.: 3D non-linear finite element modelling of traditional timber connections. in World conference on timber engineering, 2010. Riva de Garda.

[21] Hashin, Z.: Failure Criteria for Unidirectional Fiber Composites. Journal of Applied Mechanics, 1980. 47(2), p. 6.

[22] Abaqus, Analysis User's Manual, in Volume 3: Materials6.10.

[23] Franke, S., Quenneville, S.: Bolted and dowelled connections in Radiata pine and laminated veneer lumber using the European yield model. 2011, Institution of Engineers Australia, Australian Journal of Structural Engineering.

[24] Sawata, K., Yasumura, M.: Determination of embedding strength of wood for dowel-type fasteners, The Japan Wood Research Societ 3, 2002. 48, p. 138-146. 